\title{
Auslin, Michael R. 2020. Asia's New Geopolitics: Essays on Reshaping the Indo-Pacific. Hoover Institution Press, 263 pp. \$21.72 (Paperback)
}

What long appeared to be a static security environment in Asia has dramatically changed over the past two decades. The book Asia's New Geopolitics: Essays on Reshaping the IndoPacific is well-crafted and incisive research of Asia's role in a complex, unstable world. The author, Michael R. Auslin, is a world-renowned expert on the region, research fellow in Contemporary Asia at the Hoover Institution, Stanford University. The book consists of eight separate essays, which study the political, military, ideological and cultural aspects of modern Asian geopolitics using a rich set of empirical data and sources. The book is focused on the confrontation between the United States and China, while the author sees China as a threat to regional stability and prosperity.

Auslin, as a historian, pays close attention to geopolitics' methodological tools when analysing political processes, quoting Halford Mackinder and Nicholas Spykman. The author claims that Asia is the world's most important region. Even though this book focuses on China's growing role and the confrontation between the United States, Japan, and other Asian countries are not left out. Moving westward, China has also thought to expand its influence through the so-called "String of Pearls" throughout the Indian Ocean, namely ports and access points ringing the Indian subcontinent and reaching to Africa and the Persian Gulf region (p. 9). The author argues throughout the study that Washington is not doing enough to counter Beijing's growing influence. When looked in totality, the Chinese challenge is political, economic, military and regionwide, thus, so must be America's response (p. 9).

The most important theoretical innovation of this book is a new term - Asiatic Mediterranean. The author attributes this term to the American geopolitical scholar Nicholas Spykman $^{1}$ (1944) and superimposes these developments on Asia. According to Auslin, the Indo-Pacific region is of strategic interest in contemporary international relations, which can be compared to the role of the Mediterranean in the past centuries. As a strong indicator, one can take the 2019 US Department of Defense Indo-Pacific Strategy Report, which opens by stating that the "Indo-Pacific is the Department of Defense's priority theatre", announcing an explicit reorientation of US defense strategy away from the Atlantic and Middle East (p. 171).

1 Spykman, Nicholas. 1944. The Geography of the Peace. New York: Harcourt, Brace and Company. 
The book's main idea is that an effective response to China's challenge requires adopting a larger geostrategic picture of the entire Indo-Pacific region, while American policy in this direction does not meet the threat level. Auslin is convinced that US administrations have so far been wrong in their geopolitical assessments in Asia by believing they could change China (p. 26). What is to be done according to Auslin? First, the United States must consciously redraw its mental map to adopt the idea of the Asiatic Mediterranean. Washington must accept that its goal is to ensure that no aggressive power gains control over the Asiatic Mediterranean. This policy combines maintaining the balance of power and asserting America's ability to control East Asia's inner seas' waters, skies, and cyber networks (p. 14).

The author also pays great attention to the confrontation between China and Japan, calling it the Other Great Game of Asia. The emphasis on the Sino-American rivalry for global power ignores this intra-Asian rivalry, which could impact the Indo-Pacific region as it does between America and China. For thousands of years, China and Japan have been locked in a relationship even more interdependent, competitive, and influential than the much more recent one between Washington and Beijing. Each has strived to dominate or be the most influential Asian state, and their relations with neighbours at different times were directly determined by their rivalry (pp. 121-122). However, Auslin confirms his hypothesis that Japan cannot withstand geopolitical competition with China without the transformation of US policies in Asia. Island powers can rarely compete with cohesive continental States (p. 124). Although Tokyo can defend its territories in the East China Sea, it knows that its influence in the region is limited. This moment requires the continuation and the strengthening of allied relations with the United States (p. 139).

The author sees positive signs in adopting US strategic changes concerning Asia, seeing them as excellent opportunities for China's military and geopolitical deterrence. Traditionally, Americans referred to this region as Asia or the Asia-Pacific region and often focused on even narrower sub-regions, such as Northeast Asia or South Asia. As a result, the ability to conceptualise the region as a whole has been limited, including the various connections that cross ethnic, cultural, and linguistic boundaries, not to mention the challenges that the region faces. Only recently has it become more common to talk about the Indo-Pacific region. This relatively new term has been designed to provide a holistic view of the region and its diverse interests. This moment is mainly consistent with the military "area of responsibility" assigned to the US Indo-Pacific Command (p. 150).

Despite the high-quality sources, the novelty of hypotheses and the depth of conclusions, the book is not without its drawbacks. First, the excessive exaggeration of threats from China is clearly visible. The author seems not to consider the Cold War propaganda when the United States emphasised China's democratic features in the hope of getting an ally in the confrontation with the USSR. Therefore, sometimes the author's rhetoric and constant appeal to non-democracy do not stand up to scientific and historical criticism. Sometimes, the author's theses look like a panic related to China's authoritarian growth. China is a globalisation supporter, but not as it is seen from the West. It is complicated 
to determine the criticism boundaries when it does not consider the processes, practices and political motivations of different actors in international relations with a high consciousness of historical changes. The global leadership problem cannot be reduced to the primitive concept of leadership transfer from the United States to China or its lack of consistency and US leadership preservation.

Austin's book will be helpful for all who research Asia's political, economic, and sociocultural processes in South-East Asia. Numerous sources and rich empirical evidence accompany the collection of essays. The book narrates the last decade's events in the region and offers an original, sometimes "hawkish" view of the processes and practices. At the same time, the author provides several hypotheses and notions that can be considered an inspiring contribution to international relations scholarship.

Georgi Asatryan is a Research Fellow of the Plekhanov Russian University of Economics and at The Institute of Scientific Information on Social Sciences of the Russian Academy of Sciences. E-mail: asatryan.ge@rea.ru. 